\title{
MODERNIZATION OF FRONT DESK PROJECT (FDP) TRAINING CURRICULUM FOR PUNJAB POLICE
}

\author{
Saba Javed Chattha*, Bushra Batool, Muhammad Shoaib Farooq \\ Department of Computer Science,University of Management and Technology, Lahore - Pakistan. \\ Email F2017279027@umt.edu.pk \\ *Corresponding Author
}

\begin{abstract}
Front Desk Project (FDP) was initiated by the Punjab government to bridge the gap between police and public in 2015. Punjab police was facing too much complains and lack of confidence from public as a friendly service oriented organization. FDP was aimed to bring educated people in police station to deal with the complainants by using latest technology to make it easier to lodge a complaint and First Information Report (FIR). Previously Police manage their records manually but after initiation of FDP, everything was computerized and easy to follow up a case in short period of time. A training program of FDP was devised to train the front desk officers who deal with public. It was initially designed asforty days training based on computer typing skills and law at police training centers. This program consisted of basics of Law, typing skills and motivational lectures. This paper aims to identify the short comings in the training program i.e. traditional curriculum which doesn't match with the job requirement, which requires software training, physiological, behavioral, ethical trainings andalso requires practical exposure. Moreover, exploring the opportunities to propose a system for the transformation of traditional FDP curriculum composed of state-ofthe-art training methods. The proposed FDP curriculum has a capacity to enhance capabilities and real time experience for the trainees. This would also help trainers to automate the course and be helpful in police working and management.
\end{abstract}

Keywords: Front Desk Curriculum, Training, Management, Modernization of Curriculum

\section{INTRODUCTION}

The rising in numbers of crimes and dissatisfaction of the public with police[1], forced the authorities to incorporate the automatic technological solution to enhanced police availability, accelerated processes and continuous monitoring[2]. The establishment of front desk was aim that winning over public trust and satisfaction through urgent and timely redressal of public grievances. This project is the foundation stone for the future vision of paper less policing. In 2015, Front desk project was introduced by Ex-Prime Minster (Pakistan) Nawaz Sharif. Software System is based on client/server and relational database technology [3].

Previously the failure of manual complaints management system was arbitrarily undermining the policing and public service. This front desk setup in the police stations for the convenience of the public and these are equipped with the required infrastructure. The pre and post working of Complaint Management System is defined in figure 1 and 2 respectively. Civilian staff as station assistant is working for the convenience of the people. They immediately reports complaints through a centralize system. This complaint is process and the reply is given on the email address of the complainants. The complainants are handed over the electronics 
receipts.A pleasant environment to the complainants is provided at the police station so that they could lodge their complaints without any fear and hesitation [4].

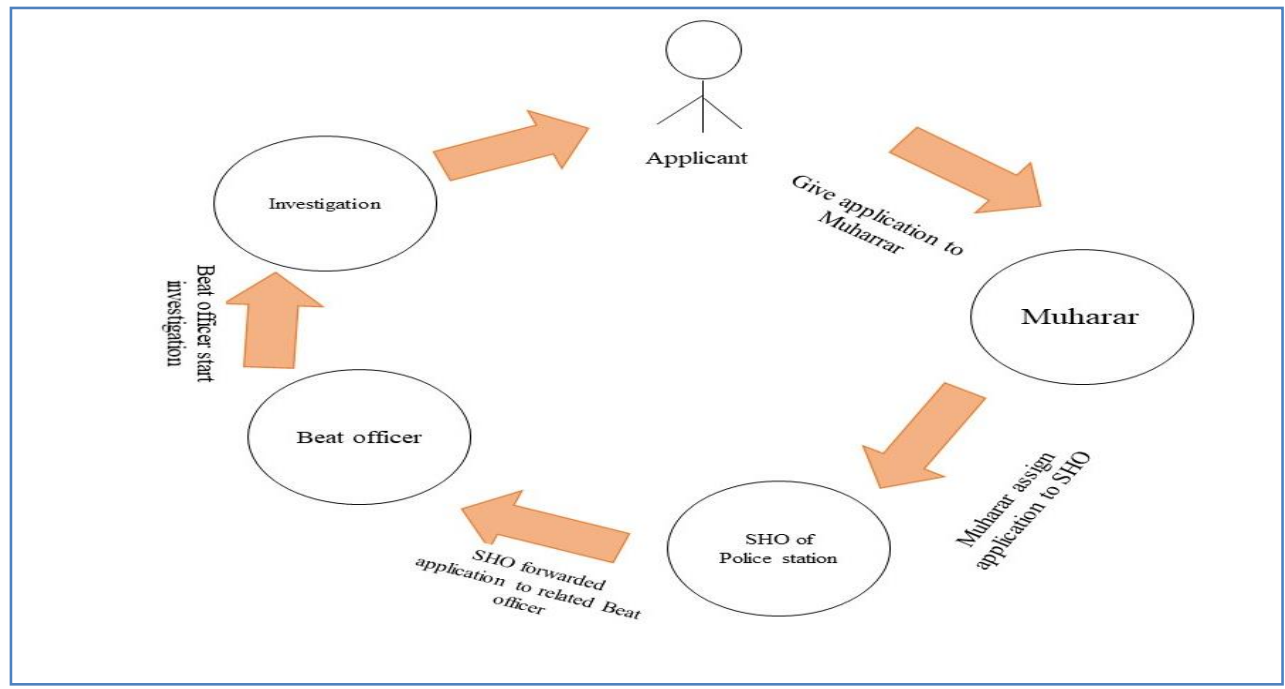

Figure 1: Pre Front desk Project Working in Police Station

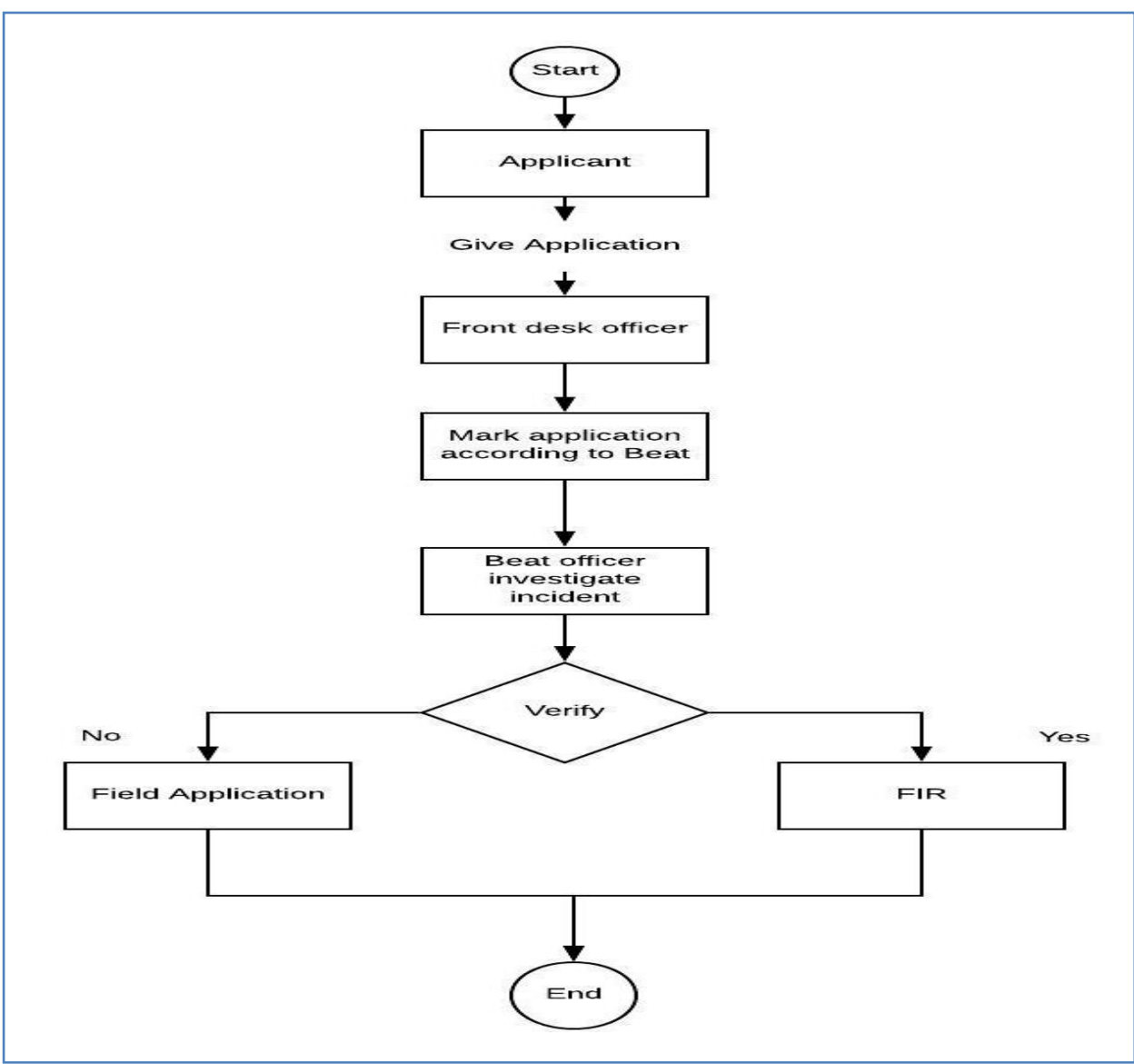

Figure 2: Post Front desk Project Working in Police Station

The establishment of front desk is the manifestation of public service delivery and to improve police image in the eyes of public at large.This projects aims to provide equal access and dignity to all visitors irrespective of their social status,caste and creed.An access which is easy,immediate and direct with respect.The breakup [5] of exiting Front Desks established at police stations in Punjab is shown in Figure 3. 


\begin{tabular}{|l|l|l|l|}
\hline District & Front Desks & District & Front Desks \\
\hline Lahore & 74 & Srgodha & 08 \\
\hline Sheikhupura & 06 & Muzaffar Garh & 02 \\
\hline Gujranwala & 21 & Rahim yar khan & 10 \\
\hline Sahiwal & 03 & Bahawalpur & 05 \\
\hline Faisalabad & 24 & Multan & 15 \\
\hline Rawalpindi & 18 & DG Khan & 02 \\
\hline
\end{tabular}

Figure 3: Breakup of Exiting Front Desks in Punjab

When a complainants comes to a police station for registration of FIR(FIRST Information Report),the front desk officer enters the application in the software specially designed for the purpose. Each application is marked with a unique number and forwarded to related beat officer. After verification of the application, Front desk officer register the FIR.The complainants are informed through return email or message.Then the FIR is sent to the concerned officer for investigation. The details may be seen in figure 4.Even the senior officers could monitor the working of police stations while sitting in their offices.

ForFDP young male andfemale officers were recruited and trained at Police Training Centres. That was a crash course programme for forty days based on traditional curriculum. This Research Paper aims at devising a comprehensive curriculum for FDP which covers modern requirements and on job work experience. This proposed curriculum is inclusive of modern concepts and state-of-the-Art techniques being followed by the first world.

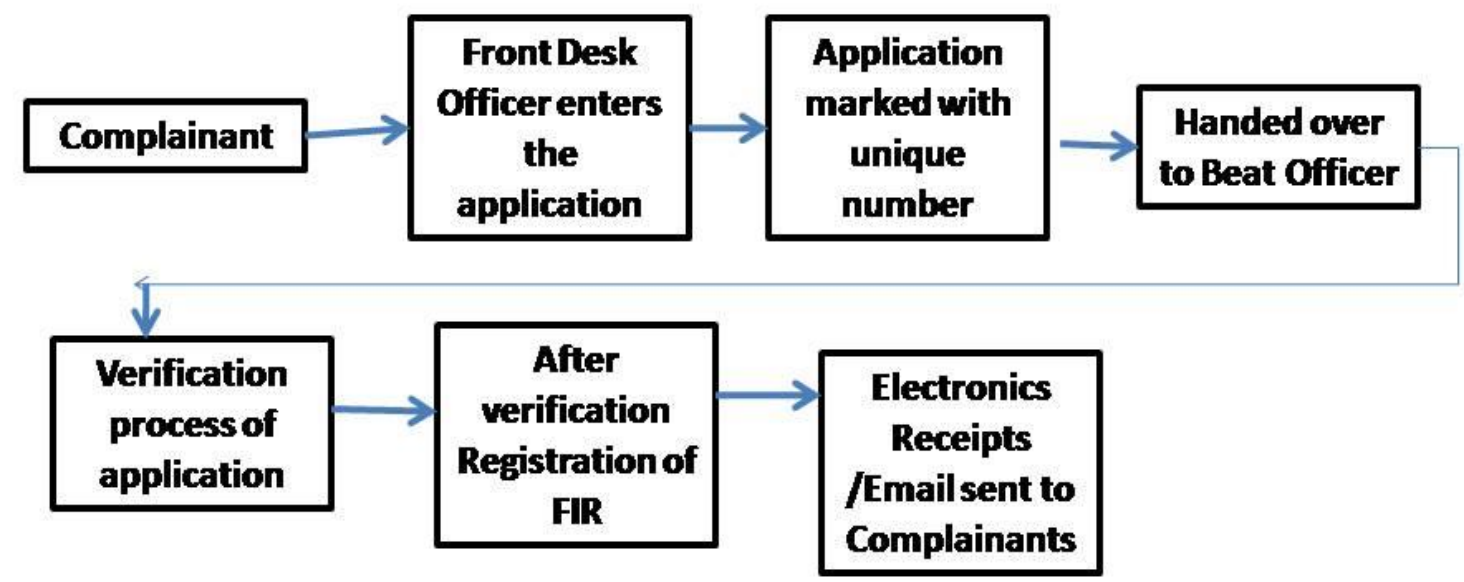

Figure 4:Flow of FIR Registration

The rest of the paper is organized as follows: following the Introduction section, we present the related work. The Front Desk Training Curriculum is discussed and some shortcomings are identified .In the Contribution section wedevisea Modernize Training Curriculum of Front Desk Project and proposed some suggestions for its improvement. Finally, we present the conclusion of this research work.

\section{RELATED WORK}

Modern concepts and technologies are being incorporated all over the world.Hassel free and paper less policing is hall mark of the developed world countries like India [6] and UAE are also using latest gadgets and technologies to make their police public friendly and efficient.Police have been reformed and trained to cope up with the challenges of this age.Modern training techniques are being adopted for police reformation.FDP training manual was just an orientation programme and lacked the real time experience. When we compare the training manual of Punjab police with India and UAE we may find certain short comings. Indian and UAE 
police training is based on real time experience,firsthand knowledge and expertise in IT solutions. The main objective of this system is to promote public interest as well as balancing the law. The other countries like United States provide the facilities for crime management which has enhanced their performance [7]Hata! Başvuru kaynağı bulunamadı. Muramatsu et al. in [8] created a system for crime investigation. The system is very helpful for investigators to identify the criminal records. E-computerized Operations [9] of Police Services paper about interactive system of people and police. People could express their concerns about crime, the possibilities of crime in their area and the police could take part in its area of jurisdiction.

\section{FRONT DESK TRAINING CURRICULUM}

Front Desk Officers were recruited as a civilian work force in the police station [10] aimed to help the visitors through IT solution and complaint management system. These young officers were trained in Police Training College Lahore.

The main objectives of the Training Program were enabling the trainees to deal the visitors with courtesy, Comprehend the Laws and procedures, IT awareness and to improve the Typing Skills.

The Training Manual(TM) was comprised of the following subjectswhich are shown in Table 1:

\begin{tabular}{|c|c|c|c|}
\hline Sr.no & Timings \Days & Course Title & Topics \\
\hline 01 & $\begin{array}{l}\text { 9:00am-4-00pm } \\
\text { Monday-Friday }\end{array}$ & Motivational Therapy & $\begin{array}{l}\text { - } \quad \text { Attitudinal changes } \\
\text { - } \quad \text { Ethics Values } \\
\text { - } \quad \text { Motivational lectures }\end{array}$ \\
\hline 02 & $\begin{array}{l}\text { 9:00am -4:00pm } \\
\text { Monday-Friday }\end{array}$ & Police rules and Law & $\begin{array}{l}\text { - PPC (Pakistan penal Code) } \\
\text { - CrPC (Code of Criminal procedure) } \\
\text { - } \quad \text { Local and Special Laws } \\
\text { - } \quad \text { Police Order } 2002 \\
\text { - } \quad \text { Method of FIR } \\
\text { - Method of Challan }\end{array}$ \\
\hline 03 & $\begin{array}{l}\text { 9:00am-4-00pm } \\
\text { Monday-Friday }\end{array}$ & $\begin{array}{c}\text { Computer Typing } \\
\text { Program }\end{array}$ & - Typing Speed \\
\hline 04 & $\begin{array}{l}\text { 9:00am -4:00pm } \\
\text { Monday-Friday }\end{array}$ & Software Training & $\begin{array}{l}\text { Public Dealing } \\
\text { - Basic Software Training }\end{array}$ \\
\hline
\end{tabular}

Table 1: Traditional Training Manual

The Training Program was comprised of 40 days, at the end an examination held in which the criteria to pass the exam was to secure $50 \%$ marks.

\section{SHORTCOMINGS IN THE TRAINING CURRICULUM}

During the course of practical implementation of the program many shortcomings [12] like ,practical exposure ,on job training, specified training according to the job description, Psychological Training,Public Dealing, Physical Training were observed in Training Program. Moreover, the whole training program lacked Summative and Formative Assessment system which is a key of every successful training program in the modern world.

It was also observed that the complete training program was based on traditional passing methodology. A proper grading system was missing in the whole training curriculum. This old dated examination system was 
not helpful in healthy competition among trainees and their career growth as $51 \%$ and $99 \%$ were equal.

\section{MODERNIZATION OF FRONT DESK PROJECT TRAINING CURRICULUM}

While studying the Training Manual of the FDP and with an effort to analyze it in the international[13] police training perspective, it was felt to develop a Model Training Manual(MTM).MTM is a guide book for a trainers on conducting training programs for civilian police staff working on a FDP.The aim of MTM is to provide the best training, empowerment and capacity building for the trainees in addressing the issues of complaint management and police record management in all its dimensions. This should help in increasing the capacity of the Front Desk Officers in attending to their duties with the high degree of professionalism and motivation.This would facilitate them to ensure complaint management with clarity,surety and certainty.Moreover sensitize them to undertake the required steps in ensuring the best care and attention to the visitors.

A Comprehensive Training Model on modern line is proposed in Table 3. The Training Program will be comprised of 90 days in which five modules have been devised.Every module consists of relevant subjects,specific credit hours and total weightage of numbers accordingly.Moreover, every trainee will be assessed at end of the each module and have to pass the exam at the end of training progamme.However if someone fails in any subject of module, hecould reappear in that subject with subsequent module's exams. The grades will be awarded to the trainees and further growth in career would depend upon the grade in the training programme. The criteria to pass the exam will be to secure $55 \%$ marks and below $55 \%$ will be failed. The Grading Criteria is shown in Table 2.

\begin{tabular}{|c|c|c|c|}
\hline Letter Grade & Percentage & $\begin{array}{c}\text { Grade Point } \\
\text { Average }\end{array}$ & Grade \\
\hline A+ & $95-100$ & 4.00 & Excellent \\
\hline A & $90-94$ & 4.00 & Very Good \\
\hline A- + & $86-89$ & 3.67 & \\
\hline B & $83-85$ & 3.33 & Good \\
\hline B- & $80-82$ & 3.00 & PASS \\
\hline C+ & $76-79$ & 2.67 & Marginal \\
\hline C & $73-75$ & 2.33 & Weak \\
\hline C- & $70-72$ & 2.00 & \\
\hline D & $65-69$ & 1.67 & 1.33 \\
\hline D- & $60-64$ & 1.00 & \\
\hline
\end{tabular}

Table 2: Grading Criteria

The Transcript and Certificate will be issued after completion of the training programme which may be seen in Figures 5 and 6respectively. This grading system would encourage a healthy competition among the trainees and result in a motivated and devoted workforce for the department.

\section{Module 1:}

\begin{tabular}{|c|l|l|l|l|l|}
\hline Sr.No & Course Code & Course Title & Hours & Marks & Weightage\% \\
\hline 1 & PS101 & Attitudinal Change & 30 & 50 & $15 \%$ \\
\hline 2 & PS102 & $\begin{array}{l}\text { Motivational therapy through } \\
\text { guests speakers }\end{array}$ & 20 & 50 & 50 \\
\hline 3 & PS103 & $\begin{array}{l}\text { Motivational tools and } \\
\text { Techniques }\end{array}$ & 15 & 50 & 15 \\
\hline
\end{tabular}


Module 2:

\begin{tabular}{|c|l|l|l|l|l|}
\hline Sr.No & Course Code & Course Title & Hours & Marks & Weightage\% \\
\hline 1 & PS201 & $\begin{array}{l}\text { Legal and Procedural issues at } \\
\text { Police Station }\end{array}$ & 30 & 50 & \multirow{2}{*}{$25 \%$} \\
\hline 2 & PS202 & General Laws (crPC,PPC) & 20 & 50 & \\
\hline 3 & PS203 & Local and Special Laws & 15 & 50 & \\
\hline 4 & PS204 & Police Order 2002 & 15 & 50 & \\
\hline 5 & PS205 & Police Rules & 20 & 50 & \\
\hline
\end{tabular}

\section{Module 3:}

\begin{tabular}{|c|l|c|l|l|l|}
\hline Sr.No & Course Code & Course Title & Hours & Marks & Weightage $\%$ \\
\hline 1 & PS301 & Role of Front Desk Officer & 30 & 50 & \\
\hline 2 & PS302 & Public Dealing & 20 & 50 & \multirow{2}{*}{$15 \%$} \\
\hline 3 & PS303 & Physical Training & 15 & 50 & \\
\hline 4 & PS304 & First Aid & 15 & 50 & \\
\hline
\end{tabular}

Module 4:

\begin{tabular}{|c|l|r|l|l|l|}
\hline Sr.No & Course Code & Course Title & Hours & Marks & Weightage\% \\
\hline 1 & PS401 & $\bullet \quad$ Computer Typing Program & 30 & 50 & \multirow{2}{*}{$20 \%$} \\
\hline 2 & PS402 & $\bullet \quad$ Software Training & 20 & 50 & \\
\hline 3 & PS403 & $\bullet \quad$ Monitoring and Evaluation & 20 & 50 & \\
\hline
\end{tabular}

\section{Module 5:}

\begin{tabular}{|c|l|l|l|l|l|}
\hline Sr.No & Course Code & Course Title & Hours & Marks & Weightage\% \\
\hline 1 & PS501 & $\begin{array}{l}\text { Practical on Job Training at } \\
\text { Police Station Level }\end{array}$ & 30 & 50 \\
\hline 2 & PS502 & $\begin{array}{l}\text { Practical on Job Training at } \\
\text { District Police Level(DPO) }\end{array}$ & 20 & 50 & 50 \\
\hline 3 & PS503 & $\begin{array}{l}\text { Practical on Job Training at } \\
\text { IT Department of Police } \\
\text { Station }\end{array}$ & 20 & 50 \\
\hline
\end{tabular}

Table 3: Modernization of Front Desk Project Training Curriculum

The FDP is focused on strengthening Police Public Relation and response against the crime and criminals. By following the above mentioned Training Model of Front Desk Officialswill be able to handle the complaints management and police station record management system efficiently with zeal to serve the fellow human beings[13]. This Manual is an effort to devise the Training Curriculum for the traineesto make them enable to use their potential fully. 


\section{Station Assistant Training Result}

(Institute by Punjab Police)

https://punjabpolice.gov.pk/

ID Name:

S201827

Employ Name: Ali Raza

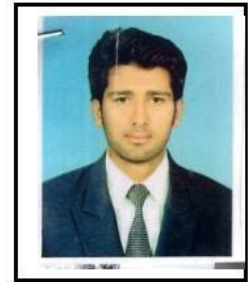

Father Name: Raza Ahmed

Post Name: SSA

\begin{tabular}{|c|c|c|c|c|}
\hline $\begin{array}{c}\text { Course } \\
\text { ID }\end{array}$ & Module 1 & Cr.hr & Grade & G.P \\
\hline PS501 & Attitudinal change & 4 & A & 4.00 \\
\hline PS502 & $\begin{array}{l}\text { Motivational } \\
\text { therapy }\end{array}$ & 3 & A & 4.00 \\
\hline PS503 & $\begin{array}{l}\text { Motivational tools } \\
\text { and techniques }\end{array}$ & 3 & $\mathrm{~B}+$ & 3.33 \\
\hline PS504 & Stress management & 3 & B & 3.00 \\
\hline $\begin{array}{l}\text { Course } \\
\text { ID }\end{array}$ & Module 3 & Cr.hr & Grade & G.P \\
\hline PS801 & Computer typing & 4 & $\mathrm{~B}+$ & 3.33 \\
\hline PS802 & Software training & 3 & A & 4.00 \\
\hline PS803 & $\begin{array}{l}\text { Monitoring and } \\
\text { evaluation }\end{array}$ & 3 & $B$ & 3.00 \\
\hline
\end{tabular}

\begin{tabular}{|c|c|c|c|c|}
\hline $\begin{array}{l}\text { Course } \\
\text { ID }\end{array}$ & Module 2 & Cr.hr & Grade & G.P \\
\hline PS601 & $\begin{array}{c}\text { Legal and } \\
\text { procedural issues } \\
\text { at PS }\end{array}$ & 4 & $A$ & 4.00 \\
\hline PS602 & PPSC/CRPC & 3 & A- & 3.67 \\
\hline PS603 & Police order & 3 & A & 4.00 \\
\hline PS604 & Police rules & 3 & $\mathrm{~B}+$ & 3.33 \\
\hline $\begin{array}{l}\text { Course } \\
\text { ID }\end{array}$ & Module 4 & Cr.hr & Grade & G.P \\
\hline PS801 & $\begin{array}{c}\text { Practical on job } \\
\text { training at PS }\end{array}$ & 4 & $\mathrm{~B}+$ & 3.33 \\
\hline PS802 & $\begin{array}{l}\text { Practical on job } \\
\text { training at DPO }\end{array}$ & 3 & A & 4.00 \\
\hline PS803 & $\begin{array}{l}\text { Practical on job } \\
\text { training at }\end{array}$ & 3 & B & 3.00 \\
\hline
\end{tabular}

\begin{tabular}{|c|c|c|c|c|}
\hline $\begin{array}{c}\text { Course } \\
\text { ID }\end{array}$ & Module 5 & Cr.hr & Grade & G.P \\
\hline PS701 & Role of FD officer & 4 & A & 4.00 \\
\hline PS702 & Public dealing & 3 & A+ & 4.00 \\
\hline PS703 & Physical training & 3 & B & 3.00 \\
\hline PS704 & First aid & 3 & B & 3.00 \\
\hline
\end{tabular}

Credit hours earned:

Credit hours for GPA:

CGPA:

Sign of Controller:

Head of Department:

Figure 6: Model Transcript 


\section{Station Assistant Training Program of Punjab police}

\section{Certificate of Position}

This is to Certify that

Sana Khan D/O Umar Khan

has cleared his/her Training Session with the excellent marks that

held on $20^{\text {th }}$ November 2018

Sign of Controller:

Figure 7: Model Certificate

\subsection{Dynamics Course Code Development}

The following points will serve as guidelines to develop three digit codes:

- First two letters should be alphabets i.e. For Police Station "PS"

- Followed by three-digit number i.e. 101

- A course code should be written as PS101

- First digit denotes the level of module and last two digits denote the course number.

\subsection{Learning Outcomes}

The trained officers for front desk will have the ability to

- Handle and maintain the police station record effectively

- Deal with the visitors politely

- To lodge the complaints and FIRs efficiently and with hassle

- To be able to use software and modern gadgets proficiently

- To manage the workload and stress

- To abreast with police rules, laws and procedures

\section{CONCLUSION}

In this paper we have analyzed the FDP project. Its training curriculum and highlighted certain shortcomings. This project aimed to bring a change in police working and service delivery to the public. No doubt IT 
revolution has brought a sea change in every sphere of life and police is no exception. Police FDP is a step forward to win the trust of public and enhance police working simultaneously. However,its training programme didn't match the job requirements. It was a crash programme with traditional police curriculum with no on job training. In the contribution portion we have suggested a comprehensive and state-of-the-art Training Curriculum [14] which not only matches the job requirements but also international standards.

\section{REFERENCE LIST}

[1] Duffy, B., Wake, R., Burrows, T., \&Bremner, P. (2008). Closing the gaps-crime and public perceptions. International Review of Law, Computers \& Technology, 22(1-2), 17-44.

[2] Osman Nasr AndEnayatAlkhider, Online Complaint Management System. Vol.2 issue 6 June 2015

[3] Front Desk Changing Face, https://punjabpolice.gov.pk/node $/ 4443,25^{\text {th }}$ November,2018

[4] Punjab Police government of the Punjab,https://punjabpolice.gov.pk/psrms, $25^{\text {th }}$ November,2018

[5] Front Desk Changing Face Punjab Police ,https://punjabpolice.gov.pk/node/4443,25 ${ }^{\text {th }}$ November,2018

[6] Ewart, J. M. (1935). Police in India. Metropolitan Police CJ, 1, 100.

[7] R.E.Fay, and J.Li, "Predicting Violent Crime Rates for the 2010 Redesign of the National Crime Victimization Survey (NCVS)," Section on Survey 10"

[8] D.Muramatsu, Y.Makihra, H.Iwama, T.Tanoue, and Y.Yagi, "Gait Verification System for Supporting Criminal Investigation," 2nd 50"

[9] E-Computerized Operations Of Police Services paper was published in javaprojects/e-copsproject.com

[10] Gershon, R. R., Barocas, B., Canton, A. N., Li, X., \&Vlahov, D. (2009). Mental, physical, and behavioral outcomes associated with perceived work stress in police officers. Criminal justice and behavior, 36(3), 275-289.

[11] Haberfeld, M. R. (2002). Critical issues in police training (Vol. 22). Upper Saddle River, NJ: Prentice Hall.

[12] Marion, N. (1998). Police academy training: are we teaching recruits what they need to know?. Policing: An International Journal of Police Strategies \& Management, 21(1), 54-79.

[13] Birzer, M. L. (1999). Police training in the 21st century. FBI L. Enforcement Bull., 68, 16.

[14] McCampbell, M. S. (1986). Field training for police officers: The state of the art. US Department of Justice, National Institute of Justice. 